\title{
Theoretical Exploration of Integrating Physical Education into Life Education
}

\author{
Jingzhi Chen*, Ying Tang \\ College of Physical Education and Health Science, Zhejiang Normal University, Jinhua, China \\ Email: *824620111@qq.com
}

How to cite this paper: Chen, J.Z. and Tang, Y. (2021) Theoretical Exploration of Integrating Physical Education into Life Education. Open Access Library Journal, 8: e8270.

https://doi.org/10.4236/oalib.1108270

Received: December 2, 2021

Accepted: December 18, 2021

Published: December 21, 2021

Copyright $\odot 2021$ by author(s) and Open Access Library Inc.

This work is licensed under the Creative Commons Attribution International License (CC BY 4.0).

http://creativecommons.org/licenses/by/4.0/

\begin{abstract}
The "14th Five-year Plan for Sports Development" issued by the General Administration of Sport of China in 2021, proposed the requirement of "strengthening the body teach fusion"; from "teach fused" point of view, this paper explores the life education theory knowledge, and provides theoretical basis for deepening physical education into life, mainly from the concept; theoretical foundation and characteristics were discussed, to establish the concept of integrating physical education into life education, put forward new viewpoints for the theoretical research of physical education, and provide higher survival significance for human life. The results show that physical education pays more attention to the development of human body, which is more closely related to the development of life education, indicating that the development of physical education can drive the development of life education.
\end{abstract}

\section{Subject Areas \\ Physical Education}

\section{Keywords}

Physical Education, Life Education, Theoretical Exploration, Education Integration

\section{Introduction}

The "14th Five-year Plan for Sports Development" issued by the General Administration of Sport of China in 2021 is the policy spirit of comprehensively deepening the integration of sports and education in China. It is the need of promoting the healthy development of youth sports and a new challenge faced by the education department. The purpose of education is to cultivate "human" process, is to the meaning of life and survival value of the spiritual embodiment, 
especially in sports is to reflect its value. As a discipline with both instrumentality and practicality, the role of physical education cannot be underestimated. It undertakes the important task of training physical feeling, improving physical quality, shaping morphological aesthetics and enriching the spiritual world. Sports is not only the basis of life, but also the form of life. No one can live without the influence of sports. This is the "universalization of sports", which lays a solid foundation for life education. Studying physical education from the perspective of life education is the perspective of re-recognition of life in the present era. It can provide physical education with new teaching materials that meet the needs of the times and society, and excavate the new knowledge implied in physical education. At the same time, it can also broaden the dimension of life education and enhance scholars' thinking and research on the theory of life education. This paper explores the theory of integrating physical education into life education, strengthens the construction of physical education and its position in various disciplines, improves people's acceptance of physical education and integrates physical education into life education.

\section{Sports into the Concept of Life Education}

\subsection{Life Education}

Different scholars have different definitions of life education, but their ultimate goal is basically the same, they all start from human life. Human beings are the dual existence of natural life and value life. Both the development and perfection of natural life and the growth of spiritual life cannot be separated from education, which is the existing form of human life [1].

Life education is to let the educated understand the natural life of people, further understand the social life of people, to help them deal with the relationship between themselves and others, and the society; The educatees should also pursue noble spiritual life by enriching spiritual life, improving cultural accomplishment and improving moral quality [2]. Mr. Tao Xingzhi struggled all his life only to pay attention to human life, that is, the value goal of life education is to create "the whole man", which is to teach from books to life, from narrow to broad, from the hand and brain of the universe, from ear to ear to eye to mind. The basic method of life education is "the integration of teaching and doing", learning from doing and doing in learning; The basic form of life education is "living education", which means education with a sense of life. The fundamental guarantee of life education is "the interaction between mind and personality". Only by paying true love to education can a fresh life be raised, and life can thrive under the cultivation of love [3]. Therefore, life education is to guide and guide college students to cultivate the ability to respect life, cherish life, develop life potential and constantly explore the value of life [4].

\subsection{Physical Life Education}

Life education is a real people-oriented education. It focuses on the comprehen- 
sive, coordinated and healthy development of students' body, mind and personality, and is committed to improving students' survival ability and improving their quality of life [5]. Physical education is a dynamic life education of people and a direct life phenomenon. It is closer to the law of life activities in essence and can inspire life and feel the fun and efficacy of life [6]. Both in terms of physical education teaching idea, curriculum objectives, or from the perspective of enhancing students physical health, education and life have internal consistency, physical education is born in normal have climbed, walk, run, jump, based on the ability to cast, give people impart ability of various kinds of sports, and applied to life activities, such as: In the single sports show personal style, enhance personal confidence, enjoy the fun of sports; In the team sports to cultivate people's ability to cooperate with the spirit of intreptitude, feel the joy of success and failure to bring education; In people's fitness and leisure life can strengthen the body, cultivate morality and prolong life.

The emphasis of the sports life education lies in the process of physical education, especially in sports theory courses and sports skill learning, teachers should consciously into life education related elements, the fusion of life education, and guide students to actively focus on natural life, social life and spiritual life, and constantly strengthen his (her) respect for life and love. The ultimate goal of sports life education is to promote the emancipation of thinking, the bloom of vitality and the realization of free life by learning sports theories and skills. Sports life education is living education process, the process of sports teaching goal is to improve people's life and health, between teachers and students the process of friendly, if teacher wants to be a middle school class mentors and students after class friends, will follow the rules of "person" of life development, according to their aptitude, to cultivate students' correct treat themselves and the lives of others. In a nutshell, seeking and the fusion of life education in physical education, is to motivate students to actively take part in sports activities, to help students search for sports education contains the profound meaning of life, let the student fully affirmed to their own life value, especially through physical education practitioners to make students become the value of life and develop [7]. Therefore, teachers need to combine the concept of life education to organize teaching in the curriculum, and naturally integrate the concept, content and principles of life education into physical education, so that students can not only learn the knowledge content in physical education class, but also receive life education imperceptibly in the process of learning. We continue to explore life education in physical education, which is also to further enrich the core quality of physical education. The concept of life education tells us that only by recognizing the process of natural life and social life, can we handle the relationship between ourselves, others and society well, edify our spiritual life, cultural accomplishment and moral quality, and pursue a more noble spiritual life. Noble spiritual life is not empty, empty talk, it is the content, principles and implementation of carrier, the main content is divided into four: 1) reconstruction of 
the sacredness of life, the life must have the curiosity, fear, worship, can not do something contrary to nature, to follow the natural growth of life, to treat the problem of life is to do everything; 2) cultivate the sense of social responsibility, cultivate the individual spirit of self-struggle, but also let each student realize the relationship between themselves and others, society, so that students develop a higher sense of social responsibility; People's life is a process of pursuing happiness and happiness, but pain is also inevitable. Happiness and pain complement each other and life and life depend on each other. Only by coordinating the relationship between life and life can we have a happy life; 3) deal with real-life problems, such as: how to deal with the problems of human relationships, how to deal with the issue of the pursuit, how to face learning and life stress and how to face social problems and so on, and bring out these problems, discussion, put forward the proposal and solution, used to internalization to each student's moral habits. At the same time, the following four principles should be followed when teaching students life education knowledge: a) The principle of universal audience, the object of life education is not only students, but all citizens, so as to avoid all kinds of social style at the cost of recreational life, such as drug abuse, excessive drinking and Internet cafes playing games all night, and so on, can create a good social atmosphere; b) The principle of spiraling forward, the process of life education is a person's whole life, we should not rush for success, we should implement it in every bit of life, so that life education can be connected with real life; c) The principle of unity of knowledge and action, in real life to teach students to achieve unity of knowledge, emotion, intention and action, improve students' life experience, let students have a healthy life; d) The principle of combining school, family, society, life education teaching is given priority to with school, family and society is complementary, let life education knowledge internalization to each student's conscious action, strengthen the interpersonal communication, to improve students' consciousness of self-help, self-discipline and self education ability, let life education to form one of the most influential education.

\section{Theoretical Basis of Integrating Physical Education into Life Education}

Sports into the basic theory of life education, life education is produced in the process of production and the development of the theory of system, for the construction of sports into life education to provide a theoretical framework and the basic theory knowledge, for the research of physical education into life provides the corresponding methodology and epistemology, made great contributions to the development of physical education.

Life education is a comprehensive subject with a wide coverage and a comprehensive knowledge system. It has corresponding links with various subject fields, including philosophy, psychology, ethics and physical education. The essential characteristics of life, the embodiment of the value of life education and 
the function and significance of physical education are discussed and studied, and the relationship between life education and physical education is explored, which can be explained in more detail in the theories of life philosophy, humanistic psychology, bioethics and physical education. This paper discusses the theoretical basis of integrating physical education into life education from the following four aspects.

\subsection{Life Philosophy}

Some scholars believe that philosophy can explain everything in the world, dust rises and dust falls. Life philosophy is a branch of philosophy, and life education explains the problems of human existence and death from the point of view of life philosophy. It can be found that life education and life philosophy are inseparable.

The philosophy of life was first born at the end of the 18th century, and its most representative work is Carl Philip Moritz's life philosophy thought "Papers on Life Philosophy" published in 1782. By the early 19th century, the thinker Friedrich Schlegel had published Lectures on the Philosophy of Life, which incorporated experience, belief, emotion and intelligence into a strong anti-rational process. This is the origin period of the formation of philosophy of life, mainly around people's perceptual thinking to unfold.

In the development of life philosophy, Schopenhauer, Nietzsche and other thinkers appeared, which promoted the rapid development of life education philosophy. Among them, the scope of life philosophy is defined: in principle, life philosophy has nothing to do with the abandonment of rationality or irrationalism, but instead, life philosophy aims to obtain a broader range of experience that can cover life practice through a new interpretation of self-consciousness [8].

In the 1960s and 1970s, different viewpoints on life philosophy were formed with the continuous rise of schools of life philosophy. The influential representatives at that time were Simmel, Dilthey, Bergersen and Wakeng, etc. The study of life philosophy has the same direction, but the research between them has different emphases. Simmel and Dilthey studied the methodology of spiritual science; What Wei Keng studied was the construction of the philosophy of spiritual life; Bergson's research is different from the previous three. He integrates life philosophy into ontology, methodology and epistemology, which greatly enriches the category of life philosophy and introduces life philosophy into various fields and disciplines.

\subsection{Humanistic Psychology}

In the 1950s, humanistic psychology was born in the United States. In the 1970s, it developed rapidly and became one of the main contents of western psychology. Humanistic psychology focuses on human value and dignity, healthy personality and the outstanding person, the main potential of human nature, expe- 
rience, as the main content, value and self-realization, so the different ideological trend of western psychology, namely Maslow's self-actualization theory, Rogers's self theory, Rollo May's existential personality theory and Burgenthal's existential analysis theory. Maslow's self-actualization theory emphasizes: "Self-actualization is a person who strives to be himself. A composer must compose music, a painter must paint, and a poet must write poetry, otherwise they will never be quiet. What a man can be, he must be, and he must be true to his own nature" [9]. Rogers' theory of personality self tells that people do not live in an objective space, but live in a subjective experience world that can feel themselves. Rogers believes that the objective self is not another person existing in people's minds. It does not direct people to do activities, but represents their own experience that can be perceived and realized by individuals, such as internalization of morality and customs in cultural norms, and their own desires, emotions, talents and personalities [10]. Rollo-May believes that human existence is the concrete existence of individuals, the existence of the moment, the existence of conscious of oneself, the existence of free choice, the existence of unity with non-existence, and the existence of development. There are three ways of existence, namely, the surrounding world, the interpersonal world and the inner world of self [11]. Bougenthal's theory of existence analysis is based on the existentialist point of view and constructs the theory of existence analysis with the content of exploring the mode of human existence, characteristics, value, function and their mutual relationship, namely, existence giving, consciousness, anxiety and authenticity [12].

Humanistic psychology, although there are many deficiencies, it is about human itself, advocates the education is a process of "teach, personhood, adult", and be able to put the holistic view of the education thought permeate into education, to teach students knowledge, feeling, idea, the education of the line, this also is the purpose of the life education to face problems. Therefore, life education is the main body, the humanistic psychology is the branch, it plays a role in promoting the development of life education, and serves for life education.

\subsection{Bioethics}

Bioethics originated in the 1970s, founded by Van Panselle Porter in the United States, whose book is Bioethics: A Bridge to the Future, which is a subject about moral philosophy of life. With the continuous development and improvement of bioethics, the encyclopedia of Bioethics edited by Lake is widely accepted at present. In his book, he points out that bioethics is a systematic study of human behavior in the field of life science and health care, and uses moral values and principles to test human behavior within this scope [13].

Some scholars believe that bioethics is mainly divided into two types of problems. The first type is the birth, aging, illness and death of people, and the second type is the three views of people (values, outlook on life and world outlook) and development issues. On the normal side, everyone needs to experience 
these problems, but with bioethics, we need to consider not only the natural law of human beings, but also values, morality and spirit, which is also the difference between us and primitive people. With the continuous progress of material life, our spiritual life can not stop at the moment. Bioethics points out a good direction and positioning for us, which is also the purpose of life education and the necessary path to improve the quality of life. In addition, the issues studied by bioethics are relatively broad, which also points out the research direction of life education.

\subsection{Physical Education Theory}

Sports is a complex social and cultural phenomenon with diversified values, goals and forms [14]. In the new era, there are natural science, human body science, humanities and social science. Therefore, the coverage of sports has a great span, and its research content is small to the fine structure of the human body, such as cell activity, muscle slide and energy metabolism, etc. Big to the body to show the various movements, such as climbing, running, jumping, throwing and so on. The wide range of sports research has laid a good foundation for the study of sports.

From the perspective of epistemology and methodology, physical education conducts comprehensive macro research on sports through the structure and value of sports and the development law and operation mechanism of sports [15]. At present, the sports science research mainly from two aspects: one is the study of the theory of sports knowledge, sports physiology, sports training, introduction to school sports study, sports study and sports biomechanics, etc., the research of these theories can guide people to explain all kinds of sports in common, and instructions on how to exercise; The second is the study of sports practice skills, including social sports, physical education and competitive sports skills teaching and training, in these sports practice skills, can sum up some sports principles and principles to guide the research of sports theory, so as to promote the development of sports.

\section{The Characteristics of Sports Integrating into Life Education}

\subsection{The Comprehensiveness of Sports Life Education}

French philosopher Voltaire once put forward that "life lies in movement" [16]. This shows that sports are closely related to people's life activities, life is the prerequisite for survival, so life activities cannot be separated from sports. Sports also enhance people's physical health, cultivate sentiment, promote the interaction of People's Daily life and improve the quality of people's life. In addition, sports can also temper people's will, enhance people's ability to resist pressure, which can lay a solid foundation for the growth process, pave the way for the future life, can let people in the difficult twists and turns, life crisis can be strong to face, dare to struggle with setbacks of the spiritual strength. Sports life educa- 
tion integrated with life education curriculum and the sports teaching activities as a starting point, to student's life and health development as the highest purpose, about life in the growth process of natural society, on the basis of the basic theory of life education and physical education teaching practice experience, search for life in the sports activities in the development of the comprehensive and scientific. The comprehensiveness of sports life education can not only enhance students' physical health, but also strengthen students' ability to resist pressure and cope with difficulties, and awaken the vitality and creativity of individual life.

\subsection{The Experiential Nature of Sports Life Education}

Sports is a kind of embodied sports, only experienced by oneself, can discover the beauty contained in sports, can feel the passion and happiness of life in sports. Then, "sports experience" can be understood as the physical feelings and life performance characteristics obtained by personally participating in sports. Among them, body feeling and life performance characteristics are a kind of life process displayed by cell activity, muscle silk slithering, body movement and emotion change.

The experience in sports life education includes not only positive experience, but also negative experience. Whether positive or negative experience, it is a kind of experience in life, a form of life display and sublimation process. Among them, the positive experience of sports has the positive performance of struggle, success, happiness, confidence and so on, which is also the positive element we should seek in sports, the value of sports life education; But also cannot ignore the negative experience, setbacks, failures, unwilling, depressed, etc also cannot be ignored, for the life of man wave, spiral growth process is to go forward, no continuous success forever, also does not have a lifetime of continuous failure, failure and success are complementary to each other, can make a colorful life phenomenon, can make a complete life.

\section{Conclusions and Recommendations}

Sports is not a short process, but a long, continuous process, and accompanies the whole life. This shows the importance of physical education to life and the long-term nature of physical education. Human education is a process of continuous development, a process of life unfolding vividly, and a matter of facing life itself [17]. The growth of life needs to look forward, and sports skills are a process that needs to be improved, which puts forward developmental requirements for the process of sports life education. Development, can be understood as, while meeting people's current needs, a prospect of future life, so that life gets long-term development process. Physical education is different from other disciplines, which pay more attention to the development of knowledge and culture. However, physical education pays more attention to the development of human body, which is more closely related to the development of life education, 
indicating that the development of physical education can drive the development of life education.

Under the background of education integration, the theoretical research on integrating physical education into life education needs to be constantly improved and summarized according to the development needs of The Times, the physical health level of students in primary and secondary schools, the learning situation of life education and the importance of life of students. At the same time, we also need to absorb and learn excellent foreign theoretical knowledge, combined with China's advanced theoretical research results and practical development status, so as to make the theoretical research of integrating physical education into life education go ahead in the world. Any educational theory, only in practice can show its value, on the basis of theoretical research, and also combined with practice research, can explore the best way of sports into life education. This article explores the physical education from the perspective of life education, constructs a new idea combined with the outlook on life, life development, life education and life education practice, explores the multi-layer significance of integrating physical education into life education, and guides students and teachers how to establish a correct outlook on life values and how to experience and cherish the whole process of life.

\section{Conflicts of Interest}

The authors declare no conflicts of interest.

\section{References}

[1] Wang, J. (2017) Life Value Theory and Life Education Practice of College Students. Intellectual Property Press, Beijing, 49.

[2] Zheng, X. (2007) Concept, Content and Principle of Life Education. China Moral Education, No. 3, 30-32.

[3] Zhu, X. and Wang, P. (2019) Tao Xingzhi's Thoughts and Practice of Life Education. Jianghai Journal, No. 1, 224-232.

[4] Chu, H. (2015) Theory and Practice of Life Education for College Students. Nanjing Normal University Press, Nanjing.

[5] Zhang, R. and Zhang, Y. (2010) Autonomous Curriculum: An Important Course Carrier of Life Education. Journal of Guizhou Normal University, 26, 62-65.

[6] Dan, Y., Li, X. and Chen, Q. (2008) Physical Education: The Origin Regression of Life Education. Journal of Wuhan Physical Education University, No. 1, 78-85.

[7] Zhou, Y. (2017) Exploring the Integration Path of Life Education in Physical Education. Industry and Science and Technology Forum, 16, 211-212.

[8] Ferdinand, F. (2000) Philosophy of Life. Li, J., Transl., Huaxia Press, Beijing, 21.

[9] Xu, J. (1987) Maslow's Self-Actualization Theory. Encyclopedia Knowledge, No. 4.

[10] Che, W. (2003) Humanistic Psychology. Zhejiang Education Press, Hangzhou, 176.

[11] Che, W. (2003) Humanistic Psychology. Zhejiang Education Press, Hangzhou, 233-234.

[12] Che, W. (2003) Humanistic Psychology. Zhejiang Education Press, Hangzhou, 
297-307.

[13] Sun, M., Xu, D. and Shao, Y. (2003) New Bioethics. Southeast University Press, Nanjing, 8.

[14] Huang, M. (2011) Introduction to Physical Education. People's Sports Publishing House, Beijing, 4.

[15] Liu, D. (2016) Theoretical Construction of Life Safety Education Curriculum System. Beijing Sport University, Beijing.

[16] You, J. (2012) Health Care Significance of "Life Lies in Exercise". Chinese Community Physicians (Medical Specialty), 14, 377-378.

[17] Zhang, Y. and Liu, K. (2018) Modernity Dilemma and Essential Return of Life Education. Chinese Education Journal, No. 3, 30-36. 